\title{
Communication
}

[Comunicação]

\section{Physical characteristics of the eggs of red-legged partridge (Alectoris rufa) reared in captivity}

[Características físicas dos ovos da perdiz vermelha (Alectoris rufa) criada em cativeiro]

\author{
S. Ribeiro ${ }^{1}$, A.F. Pereira ${ }^{2,3}$, F. Capela e Silva ${ }^{2,4}$, M.I. Ferraz de Oliveira ${ }^{2 *}$ \\ ${ }^{1}$ Engenheira Zootécnica - Universidade de Évora - Portugal \\ ${ }^{2}$ Instituto de Ciências Agrárias e Ambientais Mediterrânicas (ICAAM) - Universidade de Évora - Portugal \\ ${ }^{3}$ Departamento de Zootecnia - Universidade de Évora - Portugal \\ ${ }^{4}$ Departamento de Biologia - Universidade de Évora - Portugal
}

The red-legged partridge (Alectoris rufa) is a game bird raised in captivity in countries like England, Spain, France, Italy and Portugal, to produce fertile eggs for incubation and chicks to provide birds for hunting and restocking purposes (Mourão et al., 2010). Due to the red-legged partridge reproductive cycle characteristics, egg production is markedly seasonal, especially when fowls are raised under natural photoperiod (González-Redondo, 2006). The physical characteristics of the egg such as weight, shape, volume and surface are important for the poultry industry and in biological studies, as they can be used in research on population and ecological morphology and to predict chick weight, egg hatchability, shell quality characteristics, and egg contents parameters (Narushin and Romanov, 2002; Altuntas and Sekeroglu, 2010). The physical characteristics of eggs depend on various factors, namely the genotype, the diet, the light regime, the body weight and the age of the female at laying (French and Tullet, 1991; Etches, 1996). The effects of female age on egg characteristics in different avian species are well known (French and Tullet, 1991; Etches, 1996), however the available information concerning the red-legged partridge reared in captivity is scarce (Mourão et al., 2010).

The objective of the present study was to evaluate the effects of female age (1,2 and 3 -

Recebido em 25 de março de 2012

Aceito em 16 de abril de 2013

*Autor para correspondência (corresponding author)

E-mail: mifo@uevora.pt year-old) and month of laying (March, April and May) on the physical characteristics of the redlegged partridge eggs reared in captivity. A total of 2878 eggs obtained from a red-legged partridge local farm in Évora (South of Portugal, $\left.38^{\circ} 35^{\prime} \mathrm{N}, 07^{\circ} 52^{\prime} \mathrm{W}, 300 \mathrm{~m}\right)$ were used in this study. Females of three classes of age $(1,2$ and 3 -year-old) were housed in couples (1 male and 1 female) in flat-deck cages under a natural photoperiod. All animals were fed with a commercial concentrate for breeding game birds (21.5\% crude protein). Feed and water were available ad libitum. Eggs were collected manually, three to four times a day, to reduce the risk of damage, identified with the number of cage, time of collection and the laying date. After identification, the eggs were transported to the selection and cleaning room, and subsequently the following determinations were performed: egg weight $(\mathrm{W}, \mathrm{g})$, determined with an electronic balance; and maximum egg length $(\mathrm{L}, \mathrm{mm})$ and breadth $(\mathrm{B}, \mathrm{mm})$, measured with digital callipers. Egg shape index $(\mathrm{ES})=\mathrm{B} / \mathrm{L}$ (Romanoff and Romanoff, 1949), volume (V, $\left.\mathrm{cm}^{3}\right)$, $\mathrm{V}_{1}=0.51 \mathrm{LB}^{2}$ (Hoyt, 1979) and $\mathrm{V}_{2}=0.913 \mathrm{~W}$ (Etches, 1996), and surface area $\left(\mathrm{S}, \mathrm{cm}^{2}\right)$, $\mathrm{S}_{1}=4.835 \mathrm{~W}^{0.662}$ (Paganelli et al., 1974), $\mathrm{S}_{2}=4.951 \mathrm{~V}_{1}^{0.666}$ (Etches, 1996) and $\mathrm{S}_{3}=4.951 \mathrm{~V}_{2}^{0.666}$ (Etches, 1996) were calculated from the previously measured egg parameters. Normal distribution and homocedasticity data were assessed by the Kolmogorov-Smirnov test and Levene's test, respectively. Except for 
maximum breadth (B), all the other variables were normally distributed and had homogeneous variance. $\mathrm{B}$ was subjected to logarithmic transformation. The results were subjected to a multi-factorial analysis of variance (GLM). When significant, the means differences in the factors of variation $(\mathrm{P}<0.05)$ were compared using the Tukey-Kramer test. All tests were performed with SPSS 13.0 statistical package.

The effect of female breeder age at laying, month of laying and the interaction of both on egg weight, maximum length, maximum breadth and egg shape index are presented in Table 1 . The average egg weight $(n=2878)$ observed in this study was $18.1 \pm 1.3 \mathrm{~g}$. This is in accordance with Alectoris rufa egg weights reported by other authors (Mourão et al., 2010). There was a significant effect $(\mathrm{P}<0.01)$ of breeder age and also month of laying on egg weight. One-year- old breeders layed significantly lighter eggs $(17.5 \pm 1.3 \mathrm{~g})$ then 2 and 3 -year old breeders $(18.1 \pm 1.3 \mathrm{~g}$ and $18.0 \pm 1.4 \mathrm{~g}$ respectively). Moreover, significantly lighter eggs were obtained, on average, in the beginning of the laying period (March, 17.4 $\pm 1.4 \mathrm{~g}$ ), than later in time (April and May, 18.1 $\pm 1.4 \mathrm{~g}$ and $18.2 \pm 1.3 \mathrm{~g}$ respectively). Indeed, the lowest $(\mathrm{P}<0.01)$ average egg weight was obtained in the first month of laying (March) for the 1-year-old females (Table 1). Other authors also reported an increase in egg weight with increasing female age and as the laying season progresses, with lighter eggs in the beginning of the laying period and heavier eggs in subsequent weeks in several poultry species (French and Tullet, 1991; Etches, 1996). However, Cabezas-Díaz et al. (2005) and Mourão et al. (2010) reported that older-red legged partridges produced lighter eggs.

Table 1. Red-legged partridge (Alectoris rufa) egg weight, dimensions and shape index, according to female age (A) and month $(\mathrm{M})$ of laying (mean \pm standard deviation)

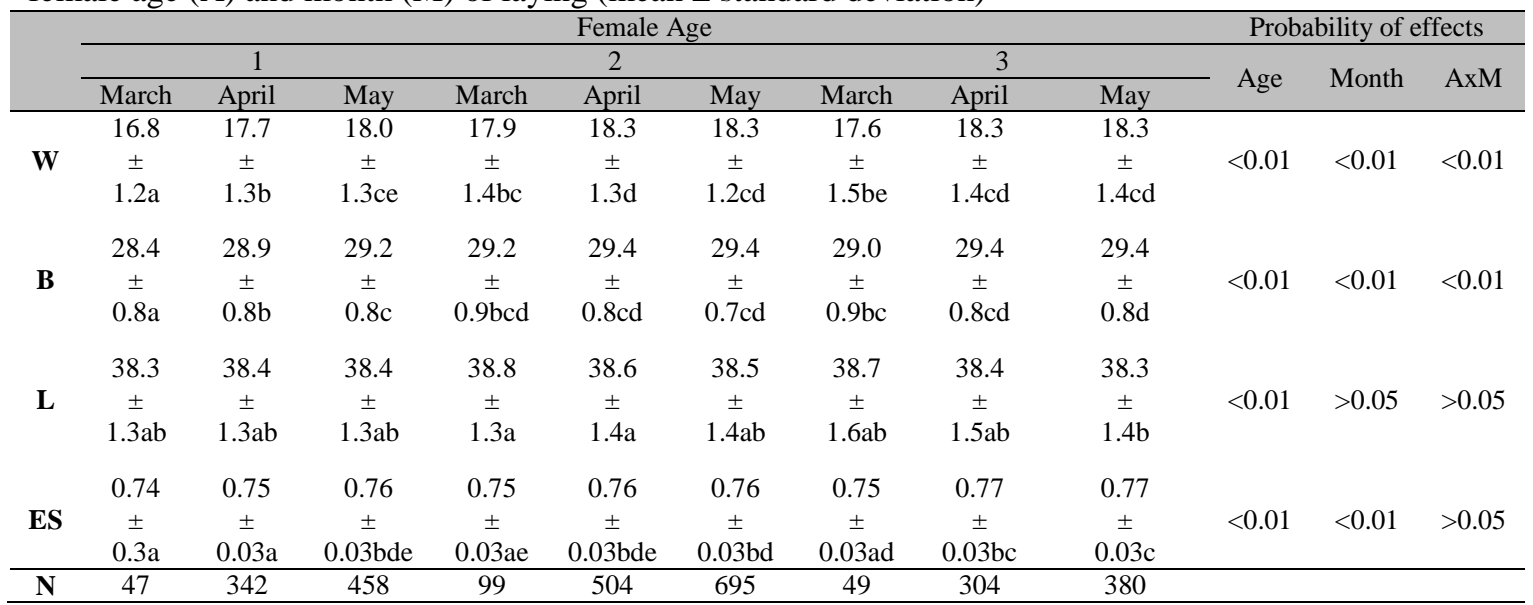

$\mathrm{W}(\mathrm{g})=$ weight of eggs; $\mathrm{B}(\mathrm{mm})=$ maximum breadth of eggs; $\mathrm{L}(\mathrm{mm})=$ maximum length of eggs; $\mathrm{ES}(\mathrm{B} / \mathrm{L})=$ egg shape index; $\mathrm{N}=$ number of eggs. Mean values within the same row followed by distinct letters are significantly different $(\mathrm{P}<0.05$; Tukey-Kramer method).

Egg length varied on average from $38.3 \pm 1.4$ to $38.8 \pm 1.3 \mathrm{~mm}$ and was only affected $(\mathrm{P}<0.01)$ by age. Two year old partridges layed longer eggs $(38.7 \pm 1.4 \mathrm{~mm})$ when compared to 1 and 3 -yearold partridges $(38.4 \pm 1.3$ and $38.5 \pm 1.5 \mathrm{~mm}$, respectively). Egg breadth was significantly lower on eggs from 1-year-old $(28.9 \pm 0.8 \mathrm{~mm})$ than from 2 and 3-years-old $(29.3 \pm 0.8$ and $29.3 \pm 0.8 \mathrm{~mm}$ respectively) females. Moreover, eggs layed in March (beginning of the laying period) had a significantly $(\mathrm{P}<0.01)$ lower maximum breadth $(28.9 \pm 0.9 \mathrm{~mm})$ than those layed later on (April, 29.2 $\pm 0.8 \mathrm{~mm}$ and May,
$29.3 \pm 0.7 \mathrm{~mm})$. Indeed, when comparing individual means (Table 1), the lowest $(\mathrm{P}<0.01)$ $\mathrm{B}$ and $\mathrm{L}$ were observed for eggs layed by 1 -yearold females, during the beginning of the laying season (March). This is in accordance with Alectoris rufa egg dimensions reported by other authors (Mourão et al., 2010). Average egg shape index $(E S=0.76 \pm 0.03)$ was also similar to those reported by other authors for red-legged partridge (Alectoris rufa; Mourão et al., 2010), Chukar partridge (Alectoris chukar; Karabağ et al., 2010) and Rock partridge (Alectoris graeca); (Tilki and Saatci, 2004). ES increased $(\mathrm{P}<0.01)$, 
resulting in eggs less elongated as the female age progressed (Table 1). Irrespectively of partridges age, ES also increased with the laying season. These changes on ES, both with partridges age and month of laying, may be attributed to an increased $(\mathrm{P}<0.01)$ maximum breadth of the eggs with a simultaneous stagnation on the maximum length.

Eggs volume and surface area according to female age and month of laying are presented in Table 2. Egg volumes estimated either way $\left(\mathrm{V}_{1}\right.$ or $\left.\mathrm{V}_{2}\right)$ were significantly $(\mathrm{P}<0.01)$ lower for eggs from 1-year-old partridges $(16.33 \pm 1.21$ or $\left.15.97 \pm 1.18 \mathrm{~cm}^{3}\right)$ than 2 and 3 -year-old breeders $(16.96 \pm 1.22$ or $16.56 \pm 1.16$ and $16.85 \pm 1.30$ or $16.47 \pm 1.29 \mathrm{~cm}^{3}$, respectively). Moreover, eggs layed in the beginning of the laying season
(March) were lower in volume than those layed later on. The effects of the main factors, age of female and month of than laying, on egg volume $\left(\mathrm{V}_{1}\right.$ and $\left.\mathrm{V}_{2}\right)$ are similar to those observed on egg maximum breadth (B) and weight (W), which was expected since those parameters are used in the estimation of $V_{1}$ and $V_{2}$, respectively. When comparing individual means, $\mathrm{V}_{1}$ and $\mathrm{V}_{2}$ significantly increased with the laying season for the 1-year-old females, however for 2 and 3year-old females only $\mathrm{V}_{2}$ was significantly lower in the beginning of the laying season (March), indicating that the equation proposed by Etches (1996) may allow a better discrimination of egg volumes (Table 2). No other published data for partridge egg volume were found in the literature.

Table 2. Red-legged partridge (Alectoris rufa) egg volume and surface area according to female age (A) and month $(\mathrm{M})$ of laying (mean \pm standard deviation)

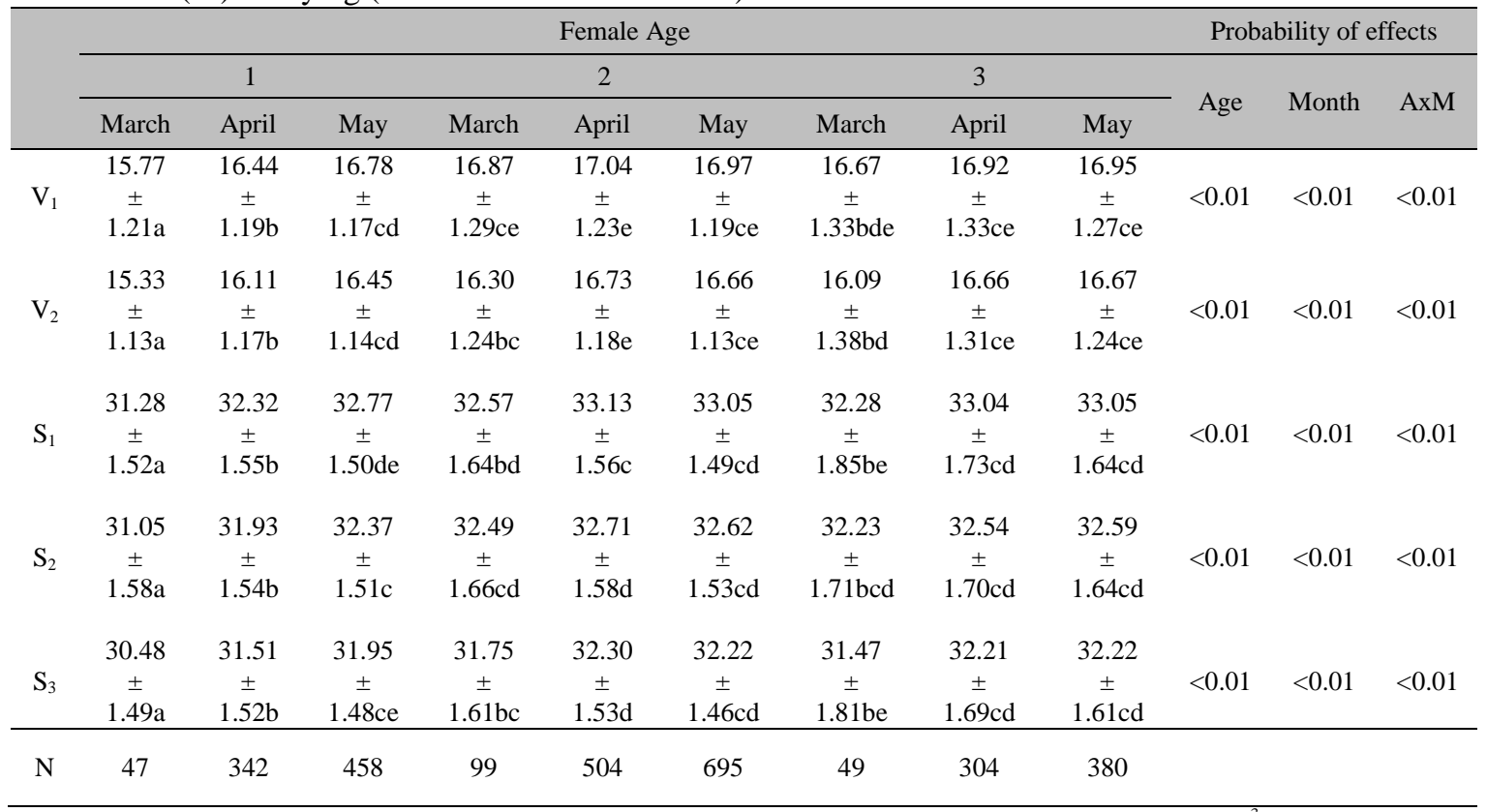

$\mathrm{W}(\mathrm{g})=$ weight of eggs; $\mathrm{B}(\mathrm{mm})=$ maximum breadth of eggs; $\mathrm{L}(\mathrm{mm})=$ maximum length of eggs; V $\left(\mathrm{cm}^{3}\right)=$ volume $\left(\mathrm{V}_{1}=\right.$ $\left.0,51 \mathrm{LB}^{2} ; \mathrm{V}_{2}=0,913 \mathrm{~W}\right) ; \mathrm{S}\left(\mathrm{cm}^{2}\right)=$ surface area $\left(\mathrm{S}_{1}=4,835 \mathrm{~W}^{0,662} ; \mathrm{S}_{2}=4,951 \mathrm{~V}_{1}{ }^{0,666} ; \mathrm{S}_{3}=4,951 \mathrm{~V}_{2}, 666\right) ; \mathrm{N}=$ number of eggs. Mean values within the same row, followed by distinct letters are significantly different $(\mathrm{P}<0.05$; Tukey-Kramer method).

Egg surface area was estimated using three different equations, $\mathrm{S}_{1}$ using a correlation with egg weight (Paganelli et al., 1974), and $\mathrm{S}_{2}$ and $\mathrm{S}_{3}$ using a correlation with egg volume, $\mathrm{V}_{1}$ (Etches, 1996) or $V_{2}$ (Etches, 1996), respectively. The effects of female age and month of laying on egg surface area were significant $(\mathrm{P}<0.01)$, irrespectively of the equation used. Younger partridges layed eggs with a lower $(\mathrm{P}<0.01)$ surface area $\left(\mathrm{S}_{1}=32.12 \pm 1.57 \mathrm{~cm}^{2} ; \mathrm{S}_{2}=\right.$ $\left.31.79 \pm 1.56 \mathrm{~cm}^{2} ; \mathrm{S}_{3}=31.31 \pm 1.54 \mathrm{~cm}^{2}\right)$ than those layed by 2 and 3-year-old breeders $\left(\mathrm{S}_{1}=\right.$ $32.91 \pm 1.53$ and $32.79 \pm 1.70 \mathrm{~cm}^{2} ; \mathrm{S}_{2}=32.60 \pm 1.56$ and $32.45 \pm 1.67 \mathrm{~cm}^{2} ; \quad \mathrm{S}_{3}=32.09 \pm 1.50$ and $31.97 \pm 1.67 \mathrm{~cm}^{2}$, respectively). As it was observed for other parameters, the effect of month is more noticeable in the beginning of laying season, and significantly increased as the laying season 
progressed, however this was not always the case for 2 and 3-year-old partridges (Table 2). As well as for egg volume, no other published data for partridge egg surface area were found in the literature.

The physical characteristics of eggs from Alectoris rufa are considerably influenced by the age of the female. The important role of red- legged partridges as game birds and the problems associated with fertility and hatchability, which may be due to bird age or egg physical characteristics, underscore the necessity for more detailed research in this area

Keywords: Red-legged partridge, Alectoris rufa, egg characteristics

\section{RESUMO}

O objetivo do presente estudo foi avaliar os efeitos da idade das fêmeas (um, dois e três anos) e do mês de postura (março, abril e maio) sobre as características físicas dos ovos da perdiz vermelha (Alectoris rufa) criada em cativeiro. O peso (W), o comprimento máximo $(L)$ e a largura máxima $(B)$ de 2878 ovos foram determinados diretamente, enquanto o índice de forma $(B / L)$, o volume $(V)$ e a superficie $(S)$ foram calculados com base nos parâmetros determinados diretamente. A análise mostrou diferenças significativas $(P<0,01)$ no peso dos ovos entre as diferentes idades e entre meses de postura, com menor peso nas fêmeas mais jovens. Observaram-se diferenças significativas $(P<0,01)$ no comprimento do ovo entre as classes de idade, mas não entre os meses de postura (P>0,05). Observaram-se diferenças significativas $(P<0,01)$ na largura máxima e no índice de forma do ovo entre as diferentes classes de idades, com valores mais elevados nas fêmeas mais velhas e no período de postura mais tardio. O volume dos ovos estimados por meio de $V_{1}=0,51 \mathrm{LB}^{2}$ e $V_{2}=0,913 \mathrm{~W}$ foi afetado significativamente $(P<0,01)$ pela idade e pelo mês de postura, bem como as áreas, $S_{1}=4.835 \mathrm{~W}^{0,662}, S_{2}=4,951 \mathrm{~V}_{1}^{0,666}$ e $S_{3}=4,951 V_{2}^{0,666}$, as quais apresentaram os mesmos efeitos.

Palavras-chave: perdiz vermelha, Alectoris rufa, características dos ovos

\section{ACKNOWLEDGEMENTS}

This work was funded by FEDER Funds through the Operational Programme for Competitiveness Factors - COMPETE and National Funds through FCT - Foundation for Science and Technology under the Strategic Project PEstC/AGR/UI0115/2011. M.I. Ferraz de Oliveira ackowledge the finantial support from the Portuguese Science Foundation (FCT) in the form of "Ciência 2008" research contract.

\section{REFERENCES}

ALTUNTAS, E.; SEKEROGLU, A. Mechanical behavior and physical properties of chicken egg as affected by different egg weights. J. Food Process Eng., v.33, p.115-127, 2010.

CABEZAS-DÍAZ, S.; VIRGÓS, E.; VILLAFUERTE, R. Reproductive performance changes with age and laying experience in the red-legged partridge (Alectoris rufa). Ibis, v.147, p.316-323, 2005.

ETCHES, R.J. Reproduction in poultry. CAB International. Oxon, 1996. 318p.
FRENCH, N.A.; TULLET S.G. Variation in the eggs of various poultry species. In: TULLETT, S.G. (Ed.). Avian incubation. London: Butterworth-Heinemann, 1991. p.59-77.

GONZÁLEZ-REDONDO, P. Influence of the laying date on the fertility and hatchability of red-legged partridge (Alectoris rufa) eggs. J. Appl. Poult. Res., v.15, p.579-583, 2006.

HOYT, D.F. Practical methods of estimating volume and fresh weight of bird eggs. Auk, v.96, p.73-77, 1979.

KARABAĞ, K.; ALKAN, S.; MENDEŞ, M. Classification tree method for determining factors that affecting hatchability in Chukar partridge (Alectoris chukar) eggs. Kafkas Univ. Vet. Fak. Derg., v.16, p.723-727, 2010.

MOURÃO, J.L.; BARBOSA, A.C.; OUTORMONTEIRO, D. et al. Age affects the laying performance and egg hatchability of red-legged partridges (Alectoris rufa) in captivity. Poult. Sci., v.89, p.2494-2498, 2010. 
NARUSHIN, V.G.; ROMANOV, M.N. Egg physical characteristics and hatchability. World's Poult. Sci. J., v.58, p.297-303, 2002.

PAGANELLI, A.; OLSZOWKA, A.; AR, A. The avian egg: surface area, volume, and density. Condor, v.76, p.319-325, 1974.
ROMANOFF, A.L.; ROMANOFF, A.J. The avian egg. New York: Wiley and Sons, 1949. 918p.

TILKI, M.; SAATCI, M. Effects of storage time on external and internal characteristics in partridge (Alectoris graeca) eggs. Rev. Med. Vet., v.155, p.561-564, 2004. 